\title{
A dissertation by Zygmunt Gloger Czy lud polski jeszcze śpiewa? [Does the Polish folk still sing?] (1905) a question about understanding of tradition, community and good remembrance
}

\section{KEYWORDS}

Zygmunt Gloger, song, folk, tradition, Slavic, community, patriotism

\begin{abstract}
Józefowicz Anna, A dissertation by Zygmunt Gloger Czy lud polski jeszcze śpiewa? [Does the Polish folk still sing?] (1905) a question about understanding of tradition, community and good remembrance. Culture - Society Education no 2(16) 2019, Poznań 2019, pp. 149-162, Adam Mickiewicz University Press. ISSN 2300-0422. DOI 10.14746/kse.2019.16.10.
\end{abstract}

The question contained in the title of the dissertation of the great folklore, researcher of the past, a lover of sightseeing trips - Zygmunt Gloger Czy lud polski jeszcze śpiewa? [Does the Polish folk still sing?] was asked, far more than a hundred years ago. It was put to Gloger by a French musician and journalist who was staying in Poland in 1901 to celebrate the opening of the Warsaw Philharmonic. He asked this way, because he was fascinated with music pieces he had heard on the stage, based "on beautiful folk motifs".

Small size, because only 24-page Gloger's dissertation issued in 1905 is an attempt to answer the problem raised in the title.

Above all, the dissertation is an expression of Gloger's regret over the changes that took place in contemporary

* ORCID https://orcid.org/0000-0002-8840-3773.

** The text was created as part of the NPRH project „Continuation of the scientific, critical edition «Distributed Letters» Zygmunt Gloger: edition of manuscripts, ethnographic writings, drawings and correspondence in seven volumes" (reg. No. $11 \mathrm{H} 170013$ 85), financed by the Ministry of Science and Higher Education in 2018-2022. 
culture, namely forgetting the role of the song for the Slav community. This is way the author knew the achievements of this community, he devoted his whole life to saving them, he could not understand how contemporary intelligentsia did not see the need for protection, as he described it "our ancient, native and indigenously Slavicnational song and music". This text is an attempt to analyze Gloger's essay Czy lud polski jeszcze śpiewa? [Does the Polish folk still sing?], extracting and developing the main theses contained in it, as well as noticing their value today, not forgetting the circumstances of creating the text over 100 years ago.

\section{Instead of the introduction - understand the purpose of Zygmunt Gloger's mission}

One can say about Zygmunt Gloger (1845-1910) with certainty that he was one-man-institution, an extraordinary personality due to the multiplicity of passions, a keen observer and commentator on everyday life from the mid-nineteenth to the beginning of the twentieth century. We can also read about Gloger: historian, ethnographer, archaeologist, publicist, writer, poet, traveller, land historian, a fervent promoter of collective memory, folk culture. One should not forget how well educated he was - he was graduated from the Main School and the Jagiellonian University and how many offices he held (member of the History Committee of the Academy of Skills in Krakow, counsellor of the Committee of the Land Credit Society in Warsaw and the first president of the Polish Sightseeing Society). In addition, such eminent figures of Polish history as the writer - Józef Ignacy Kraszewski and ethnographer - Oskar Kolberg, exerted a decisive influence on shaping the interests of the young Gloger, namely ethnographic and archaeological journeys around Poland and Lithuania. ${ }^{1}$

Reading numerous texts by Gloger (over 800 items in the bibliography), it is hard not to notice how in love he was in his native land, which was Podlasie, how great he was to her patriot. The goal of his life was to understand the problems of the rural people, who he perceived as a representative of the once great Slav community, their mentality, worldview and to save their legacy in memory for future generations. Gloger was above all aware of the fact that saving the cultural heritage

\footnotetext{
${ }^{1}$ More about Zygmunt Gloger see: https://literat.ug.edu.pl/autors/gloger.htm The website has also been translated into English language.
} 
of the departing world, its textualization in the era of partitions ${ }^{2}$ in historically Polish areas, as well as animation, propagation, were a method of saving Polishness, raising the spirit of the national community. Hence, leaving his native Jeżewo, ${ }^{3}$ he collected almost everything (stones, bones, words) on his carefully prepared archaeological expeditions, it can be said that he was collecting just in case - what if after some years something could prove invaluable.

Such terms as a collector or missionary perfectly reflect the nature of his activity. He wrote about himself a "literary" (from everything that can be written down), while the missionary character of his work consisted in a total conviction of the importance of resuming the old Slavic traditions, which he considered the core of national identity. The ancient songs indispensably accompanying rituals, songs as a mirror of feelings, he considered them the focus of Polishness, this primal one belonging to the Slavic soul. In addition, his romantic soul, believing in the revival potential of old songs for the enslaved Polish nation, who was deprived from the state, which for decades was no longer on the world map, demanded positivist activity, social utility, sharing what he gained during his escapades, mediation between people and intelligentsia. Considering himself as a provincial man, he also had a need for the mission of seeking mediation between modernity and tradition (Lawski, 2015: 31).

For the above purposes, Gloger began to publish and distribute books for free to the rural population, containing old elements of Slavonic ritual, preserved on Polish soil (cantonal songs, games, riddles, fairy tales, etc.). It will not be an exaggeration to say that he did everything in order to re-practice the recent traditions by the people of his time. He knew that just writing down a song was not enough that it would not survive in the writing itself, however, it would be different if it was sung. Even obsessive desire to protect, save from oblivion, as he himself wrote before "a loss", and thus writing down, and then passing on, boldly sharing fathers' heritage, were the most important to Gloger, more important than methodological reliability, precision of quoting from where he wrote it (these elements of heritage cultural), under what circumstances and from whom. The ambitions of writing down and resurrecting traditions were key factors to the collector of Jeżewo-key

${ }^{2}$ From 1772 to 1918, Poland was not on the map of Europe. This period in the history of Poland and Lithuania (the Polish-Lithuanian Commonwealth, the First Republic of Poland) is defined by the days of the partitions. Due to the neighbouring countries of Russia, Prussia and Austria, three partitions of the First Republic of Poland took place, its territories were incorporated into three partitioning powers (hence the name „partitioners” and three partitions: Russian, Prussian and Austrian).

${ }^{3}$ Jeżewo is the name of the village in the present-day Podlasie voivodship in Poland. It was a family estate of Gloger, in which he lived from 1872 and there for 40 years he completed a rich library. 
factors, above all, if we also see the context of the era in which he lived. And he lived under the partitions, in the Russiafied area (in the Russian partition), in the hectic times of two uprisings, ${ }^{4}$ defeats of which he undoubtedly could not get over.

Therefore, coming back to the texts of the "writer" from Jeżewo, that prism of the times in which he acted should be especially taken into account. The specters of the nineteenth-century social and political events constitute the obvious context of the mission of bringing the folk songs through Gloger to subsequent generations. The nervousness of the era also infected Gloger himself, it made him hurry with what he was doing, he was afraid of the passage of time, that there was so much left to save ("writing down") that he would not be able to make it, that it was so late. Perhaps endless sightseeing tours were a cure for the internal anxiety suffocating him. Gloger, believing in the deep, rebirthful power and strength of tradition, confirmed by the age of existence, can be presumed that he also looked for his identity, himself, in cruel times of inability to be himself (Polish), and thus by revitalizing age-old content he wanted to wake up identity in oppressed countrymen. That is why he, even if he mythologized, glorified the people together with his folklore, he did so for the sake of waking up the Slavic spirit of struggle, remembering that the Slavs cannot let the songs to be taken away, because taking Slavic songs would mean that he would cease to be a Slav.

This text is an attempt to analyze Gloger's essay Czy lud polski jeszcze śpiewa? [Does the Polish folk still sing?], extracting and developing the main theses contained in it, as well as noticing their value today, not forgetting the circumstances of creating the text over 100 years ago, in 1905.

\section{Important question}

The title, a serious question - Does the Polish folk still sing?, was asked by a French musician and journalist staying in Poland in 1901 on the occasion of the opening of the Warsaw Philharmonic. He asked Gloger this way, because he was fascinated with music pieces heard on the stage "on beautiful folk motifs" (Gloger, 1905: 5). That question, at that time, did not get an answer, which Gloger checked in the press (including "Kraj"). However, it did not give him peace. He again asked this question to himself and the future generation in a publication by Gebethner

\footnotetext{
${ }^{4}$ We are talking about the November Uprising otherwise known as the Polish-Russian War of 1830-1831 and the January Uprising referred to as the largest Polish national uprising, also against the Russian Empire, proclaimed January 22, 1863 and continued until autumn 1864. Both plots fell, which was met with larger restrictions of the partitioner (Russia) against the Poles.
} 
and Wolf published in Warsaw in 1905, by Józef Jeżyński, a small print-out, only a 24-page dissertation, a literary form reminiscent of an essay entitled Czy lud polski jeszcze śpiewa? [Does the Polish folk still sing?]

I perceive his dissertation as the expression of the changes that occurred in contemporary culture in historically Polish lands (although Poland was not present on the map of Europe as a result of the partitions of 1772-1918). ${ }^{5}$ Gloger claimed that there was a situation of not remembering the role of the song for the Slav community, singing went into oblivion, the songs had been "forgotten".

Analyzing the text, I noticed three issues that Gloger addresses in the following order: the meaning of the song in the history of the Polish nation, but also of the entire Slavdom (the area inhabited by the Slavs), then an attempt to explain how it had come to the state, present to the Author, in the culture of the Polish nation which was the disappearance of singing, as well as presenting their activities in the field of saving folklore, not forgetting about other great folklorists, lovers of songs and folk legacy.

\section{Hey, the folk song!, You are the ark of the covenant - about a role of a song according to Gloger}

When analyzing the text of Gloger, it is difficult not to notice the analogy with fragments of Pieśni Wajdeloty [Wajdelota's Song] contained in the poem of the great Polish poet Adam Mickiewicz Konrad Wallenrod (published in 1828). In Wajdelot's Song, Mickiewicz, as Gloger does later, emphasizes the importance of the folk song of the people. The strength of the folk song lies, as Mickiewicz argued, in its prehistoric existence. The folk song is a link between generations ("ark of the covenant"), sacredness and treasury of knowledge ("thoughts with yarn", "feelings with flowers"). It gathered the emotions and desires of the nation, its history, glorious deeds, information about the heroes, but also the traditions of everyday life for generations. Gloger, the Romantic personality to a large extend, took over as his own message, the power of folk messages and considered them the highest patriotic duty to cultivate them (Dobroński, 1998: 92).

5 The lands about which Gloger writes, as a result of the partitions, belonged to Prussia and Russia, Gloger conducted his touring trips mainly on the eastern frontiers of the Kingdom of Poland, the former Borderlands of the Polish-Lithuanian Commonwealth, which resulted in, among others, publication by the Dolinami rzek. Opisy podróży wzdłuż Niemna, Wisty, Bugu i Biebrzy [Valleys of rivers. Travel descriptions along the Nemunas, Vistula, Bug and Biebrza] of 1903. 
At the very beginning of the dissertation whether the Polish folk still sing? he underlines the merits of songs in centuries-long struggles with the occupiers. ${ }^{6}$ Relying on the words of the outstanding Polish chronicler Jan Długosz, he evokes the example of the song of Bogurodzica [The Mother of God], which was called the battle song and the victorious song, which warmed up the fight, pouring courage ${ }^{7}$ sinto warriors, fighting people.

In the Encyklopedia staropolska [Old Polish Encyclopedia] Gloger places the slogan of the song, hence on its pages you can read more about the age and meaning of the song for the entire Slav community, and thus for the Polish nation, as part of it. We read: "Passion for song, for play and dance has for centuries been an outstanding feature of the national character of Poles, as well as all indigenous Slav peoples" (Gloger, 1900-1903). Gloger recognized the song and song singing “(...) as a feature that distinguishes the whole «Polish nation» from the earliest times; in addition, connecting it to other Slavs" (Ławski, 2014: 33).

According to the ethnographer from Jeżewo, the music and poetry of the Polish people is the essence of Polish identity and, hence, Slavicness. It reminded us of what was certain in times of uncertainty (the ethnographer had in mind the disadvantages of the national spirit of time, the non-existence of the Polish state on the map), namely the tribal community from which Poland once emerged, from which the nation was shaped with its identity. Songs and music accompanied all the circumstances of the Slav community, they were a natural part of everyday existence, it was hardly her core. Practically every reason was good "to folk to create and sing songs" (Gloger, 1900-1903). Also in folk fairy tales the song becomes an important motif(Grochowski, 2018).

It should be explained in this place that "folk" means the entire Polish nation as part of the Slavic community, for which the song was a being, the meaning of life. Only later (Gloger talks about the era of the "Zygmunts", ie Polish kings from the last Jagiellonian dynasty, Zygmunt Stary and Zygmunt Augustus), the song enters

${ }^{6}$ All the time considering the context of the nineteenth century and the existence of the Polish nation under the partition, Gloger noticed specific danger in nationalist organizations, where he lists „Hakata” (colloquial name of the German nationalist organization „Deutscher Ostmarkenverein” founded in Poznan in 1894), which fueled anti-Polish moods, led an anti-Polish policy for Germanization in the Prussian partition, until it was dissolved in 1934. Gloger could not reconcile himself with the fact that in his scientific research and the fruitful articles, Germany omitted the history of Poland and Slavdom.

${ }^{7}$ Jan Długosz, one of the most renowned chroniclers writes, how the echoes of the songs of the Mother of God began, one of the greatest battles in the history of medieval Europe. Look more broadly: Samsonowicz, 1984. 
into peasant huts, becoming the "poetry of the folk" in the sense of people living in the village. Since then, only this social layer - the peasants has cultivated songs.

Until then, however (mainly in the Middle Ages) not only important historical events were sung in "all kinds of songs" called heroic or praised, Gloger also quotes the importance of religious and secular songs, here feasts and rituals (wedding and funeral). The song carried on in honor of the heroes, but also as an expression of despair, commemoration of the harm done (example of the Polish song of 1462 Pieśń o zabiciu Andrzeja Tęczyńskiego [Song about killing Andrzej Tęczyński] or a song Stała nam sie nowina Pani zabiła Pana [Here is the news the madam has killed the master], which became the inspiration for writing the ballad Lilie [Lillie] by Adam Mickiewicz). They were also sung under the yoke, in captivity, which was an expression of a kind of struggle, defiance and courage. Singing meant not to give up (even if the Polish national anthem is such a symbol of national sovereignty, and its melody was based on the motives of the folk Mazurka).

\section{How the disappearance of singing occurred}

"But it's not about old times that we are here" - writes Gloger further in the debate (Gloger, 1905: 7). Does the Polish folk still sing? Knowing the genesis of songs, their social role (especially patriotic), calling the song "the mental treasure of the folk" , makes the diagnosis that today and "the rural people sing far less" (Gloger, 1905: 11). Gloger is interested in how this happened, what are the reasons for this, and the subsequent pages of the essay are devoted to it.

It should be explained what Gloger understood by the word "folk". From today's perspective I know that the term "folk" is an ambiguous concept: Firstly, today the term folk can be understood the broad masses of both rural and urban populations, a political group, a political community, a national community, a society. Secondly, we use the word "folk" when we mean a lower class in society, the so-called municipalities, common people, but also the old peasant layer, the agricultural people. Nowadays, in the first sense, instead of using the term folk, the term people or society will be more precisely used as sources of power (Canavan, 2008; Zbrzeźniak, 2015: 135-140). In the second sense, the term "folk" functions only historically (the peasant layer existed from the Middle Ages up to the middle of the 20th century), just like folk culture, as the sum of the products of the old rural local communities (Burszta, 1987). I agree with Łukasz Zabielski, who claims that it is difficult to clearly define what exactly Gloger understood as "folklore" and "folk". As Gloger believed that the core of the Polish nation is ancient Slav, Gloger 
seems to be close to the romantic notion of "folk" as the one preserving the necessary traditions, beliefs, customs of this pre-Christian Slavdom, whose heritage, the author believed, should be derived to this day (Janion, 2016).

In the dissertation Does the Polish folk still sing? the term "folk" appears, however, as the peasant layer, the population of the turn of the 19th and 20th centuries inhabiting Podlasie villages, as special representatives of the departing, former Slavic community.

Thus, returning to the first signs of disappearance of the self-made creativity of the people/Polish nation/Slavic community, Gloger remarks them already in the days of the above-mentioned "Zygmunts". He speaks of a slight disregard for that "(...) everything that is not sanctified by printing and the name of the author signed." (Gloger, 1905: 12). Therefore, among the nobility, at the courts, they ceased to be intuitive, self-conscious, home-style, traditionally to sing, hence the song stopped under the "straw thatched roof" in the villages.

In turn, when from the middle of the 19th century, the printed word began to appear in the villages, a situation similar to that in the courts occurred. The people living in the village started to be ashamed of the unwritten word. There was a paradox - with the spread of education and the disappearance of illiteracy the disappearance of oral creativity started, misunderstanding of its value and wealth. What's more, thought was born among the rural population that "old unprinted songs are only the property of illiterate common people." (Gloger, 1905: 13). Gloger clearly expresses his concern at the fact that the literate peasants did not want to write old songs from "illiterate women" because they could not understand what value they could have since there were so many printed books. And here came the researcher of the ancient times from Jeżewo with his mission - collecting, translating, spreading, valuing this unpaved, forgotten heritage of his forefathers. However, it was a bit too late, because the people "passing the torch" of education from village to village did not let its residents know that it was good to get to know the new, but at the same time not forget the old and (this type of thinking) became Gloger's motto, referred to today, which exactly says "It is good to know foreign things - but ours - it is a duty."

Thus, the cosmopolitization of the lower social strata, as Gloger claims, completed the matter. Through the cosmopolitization of the village the collector of

\footnotetext{
${ }^{8}$ Encyklopedia staropolska [The Old Polish Encyclopedia] (volumes 1-4 1900-1903), repeated many times, was the culmination of Gloger's achievements. This work was reliably prepared on the basis of historical sources which no longer exist today. The quoted phrase appears as the motto of the Old Polish Encyclopedia. It is visible on the cover of the issue, see: Encyklopedia staropolska, https:// literat.ug.edu.pl/glogers/index.htm, accessed: 10.01.2018.
} 
antiquity understood, the negative effects of its modernization, becoming a suburb of the city, without preserving its identity (customs, routines, and legacy stories). The city took people to the emerging large companies - manufactories, changing thinking, needs. The author writes in the dissertation: "this must have a negative impact on the traditional Slavic tradition of the Polish people," which was the need to express emotions through songs (Gloger, 1905: 12).

\section{Great lovers of songs}

Zygmunt Gloger in his dissertation reminded that "civilization and education do not have to lead to cosmopolitanism. Such effects bring pseudo-civilization, whose products are suburban and factory pubs with dances, cards, cigarettes." (Dobroński, 1998: 91). He was referring here to the cultural disadvantage of the phenomenon, disregarding the issues of the deception of morals, namely the polluting of the Polish language with language borrowings or the unreflective adoption of foreign fashions by Poles. Gloger was captured by language as the basis for the identity of the community and homeland, and the centuries-old family traditions were supposed to be a counterweight to the "political oppressiveness of the border lines." (Kowalczuk, 2017: 37). In the difficult times in which he had to live, he could not calmly look at, how he wrote, the wave of "influences from the west and the east," thereby forgetting the Polish language in singing in the Polish language (Gloger, 1905: 15).

He could not understand how the nineteenth century intelligentsia did not see the need to protect, as he described it "ancient, national, beautiful, music and poetry of the Polish folk" (Gloger, 1905: 4). In the dissertation, his sorrow sometimes takes on a tone of indignation. He wrote "the loss of this song and music would be a simple disgrace for us." (Gloger, 1905: 14).

He wanted to counteract this "disgrace", but he failed to obtain support, he could not ask for it directly (the issue of tsarist censorship). ${ }^{9}$ So, he acted practically alone, for the model and inspiration, having the works of his predecessors (especially Oskar Kolberg). Knowing well the genesis of the songs, knowing that only in the villages one can hear them and rather timidly, he personally began to carry them. And here he was a positivist in a full swing. This attitude was expressed

\footnotetext{
${ }^{9}$ Strong regime tsarist censorship, did not allow writing about the values of national culture directly, probably that's why Gloger are looking for ways of expression, instead of the Polish nation uses terms Slavic soul, Slavic community.
} 
in the social commitment "(...) in practical and anti-utopian attitude, strong and I would say, uncompromising attachment to tradition, to real work, and not to writing about the salutary role of work" (Ławski, 2017: 168).

Gloger believed that by transmitting this element of the great Slavic community to successive generations, he stimulates patriotism in the nation. As Adam Dobroński remarked, "The presentation of tradition was another opportunity to show the unity of the nation despite administrative and state divisions" (Dobroński, 1998: 91). Piotr Dahlig wrote about a conscious revival of folklore in Polish territories by Gloger, as “(...) anticipating the effects of enfranchisement, combining (Gloger) the literacy with the popularization of annual ceremonies in Podlasie, distributing greeting cards with rural songs in the 60 s of the nineteenth century." (Dahlig, 2013: 177).

Thus, the folklorist at his own expense published small-sized booklets, encouraging the rural people to "love their old songs and customs." These included Kupalnocka [Midsummer night] (1867), Anula - święte wieczory [Anula - holy evenings] (1868) and finally books for the people covering "(...) the collection of the most beautiful old songs, melodies, passes, parables, customs (...) in a word of all that being the most ethical and homely should be forever in the mouth of the people, as a necessary pledge to the spiritual creativity of future generations." (Gloger, 1905: 17). You can mention here: Skarbczyk - dumy i pieśni - 100 śpiewów z ust ludu [Skarbczyk - pride and songs - 100 songs from the mouth of the folk] (1894), 573 krakowiaków [573 krakowiaks] (1877); Kujawiaki, mazurki, wyrwasy i dumki pomniejsze [Kujawiak, mazurkas, wyrwas and minor dumkas] (1879); Kujawiaki i dumki [Kujawiaks and dumkas] (1892); Mazurki i wyrwasy [Mazurkas and Wyrwas] (1892); Baśnie i powieści [Fairy tales and novels] (1879); Gody weselne - 394 pieśni weselnych $z$ objaśnieniami [Wedding anniversary - 394 wedding songs with explanations](1880).

From the beginning to the end, these books were intended for the rural social class, and the author wholeheartedly believed in their missionary nature. Incidentally, this purposefulness and extraordinary historical consciousness, as Maria Maroszek wrote, "(...) caused that nowadays we have to deal with the treasury of knowledge about folk tradition in this area" (reference to Podlasie - north-eastern part of modern Poland) (Maroszek, 2002).

Great folklorists - fans of songs that cannot be mentioned by Gloger in the dissertation, along with their merits for national culture were: "Wacław Zaleski, Kazimierz Władyslaw Wójcicki, Żegota Pauli, Józef Konopka, Lipiński, Gluziński, Kornel Kozłowski, Izydor Kopernicki” (Gloger, 1905: 7) and the most eminent Gloger's master, tireless as he writes about him, "a collaborator in dredging the 
mind treasures of the people" (Gloger, 1905: 9) mentioned above - was Oskar Kolberg. He also does not forget about collecting song by prominent musicians/composers: Janu Karłowicz, Lithuanian violinist Michał Jelski or Zygmunt Noskowski (with the last he published an impressive collection Pieśni ludu [Songs of the Folk] (1892).

He writes about the merits of Kolberg "(...) he alone creates the whole library of ethnographic music" or "this great worker, from the mouth of the Polish people within half a century (from 1840 to 1890) he wrote 10,300 melodies (along with the words of the song), not counting those who left unpublished at the time of his death, and those that he drew from the people of Russ and put in eight volumes including: Pokucie, Przemyskie and Chełmszczyzna, as well as Lithuanian melodies." (Gloger, 1905: 9).

Gloger reports that the music and poetry of the people is a treasury of inexhaustible, radiant power from which the greatest patriots drew inspiration. We read: "After all, people standing at the top of spiritual civilization, such as: Mickiewicz, Chopin, Moniuszko, refreshed with this familiarity, drew inspiration from song and folk music." (Gloger, 1905: 14).

From today's perspective the timelessness and omnipotence of folk art is explained by Piotr Dahling with the words:

(...) folk singing encodes the connection of singing-word, playing, dancing, which is the principle of the art of ancient times and refers generally to the early phase of humanity. This gesture, the openness of the musical form, the link between art and the images of nature also affected the nationally proliferated work of Fryderyk Chopin. The ability of the heritage of folk culture to inspire people from outside is a value both in itself and relational. How many artists', especially composers spirit (...) were uplifted by the presence of folk culture, not only as a source of direct inspiration, but also understood in the Arcadian way (...). (Dahlig, 2013: 178)

\section{A few words of summary}

Today we know that many monuments of folk culture have gone forever and the memory of them and their ideological value has been lost. The part that survived, as the authors of the report on the state of traditional musical culture show, owes its survival to " $(. .$.$) the folkloristic movement developed in Poland, the activity of pal-$ aces/centers of culture of various levels (communes, counties, provinces, regions) or organizations (e.g. to rural folklore groups), various types of folklore groups (larger - so-called song and dance bands, smaller - bands or singing groups), fes- 
tivals and song and folk music, folk dance competitions." (Grozdew-Kołacińska, 2014).

Special attention deserves the festival „Dawne Pieśni, Młode Głosy” [“Old Songs, Young Voices"]. This is a special competition for the reason that it is the words of Gloger's dissertation Does the Polish folk still sing? - "this song and music is going to be a simple disgrace for us", for the founder of the Music Society "Słopiewnie" became a signpost to organize the festival. Since 2007, in Waniewo, in the Podlasie voivodship, you have been able to hear how young people sing old songs. You can hear the sounds of, among others, Podlasie, but also Kurpiowszczyzna, Belarus, Lithuania and Ukraine. Other examples of sharing with future generations a piece of age beauty, good memory that forces you to contemplate, think and feel are, among others "Sabałowe Bajania" ["Sabala's Tales"] (competition for Storytellers, Instrumentalists, Singers or „Święto Dzieci Gór” [“Children’s Day Festival"] (International Festival of Children's Regional Bands), "Na Podlaską Nutę" ["On Podlasie Note"] or a festival "Z Wiejskiego Podwórza” ["From the Village Yard"]. ${ }^{10}$

Gloger in the dissertation Does the Polish folk still sing? saw that the world was changing, he saw the beginnings of change, which today we call globalization, the culture of consumption, the mass culture. With the non-existence of the Polish state on the map, the more insistent he was on the inheritance of fathers for the survival of national identity. This Gloger's question about "singing" is also, above all, a question about the need for community, sharing national treasures, such as traditions, including songs that raise especially the memory of strong cards of micro and macro history, in times of crises and changes.

On the centenary of Poland's celebration of independence, which fell on November 11,2018 , it is difficult not to verify the thinking about the national community, which also brings to mind the understanding of patriotism. And here the collections of Gloger, material and intangible folk culture of the native land testify to its authentic patriotism. Learning from his biography, appreciating the achievements, has value and sense. Gloger did not focus on the enemies of his non-existent homeland, on many centuries of prejudice, but on discovering wisdom in the national cultural heritage, and therefore on constructive, good remembrance. In this way he loved his homeland - not fighting armed directly but building up the resources of history, saving the achievements of the past for the future. In addition, the folklorist with his commitment, diligence, reliability at work, a sense of social

${ }^{10}$ XXIII Festival of Many Cultures and Nations „Z Wiejskiego Podwórza” [“From the Village Yard"] 2018, http://www.festiwalczeremcha.pl, accessed: 10.01.2018. 
responsibility, where at his own expense popularized disappearing traditions, is the necessary authority in today's the dilemma of values, uncertain authorities, unhealthy individualism, and excess of useless information. ${ }^{11}$ Nowadays, one of the hot problems is the rise of nationalist moods, right-wing views are becoming fashionable among young people, racist and patriotic behaviours are tragically misunderstood; a bad understanding of bonding as grouping against the Other noticeable is, therefore it is worth remembering about the attitude of Gloger. Writing even this text Does the Polish folk still sing? one has the impression that he did not forget about the essence of education, which is the formation of pro-civic bonds, in the sense of mutual sensibility, respect for memory, Christian-humanistic trust (Ingarden, 1987). He wanted that our future was built on things extracted from the national past, that were good and beautiful and therefore human.

\section{Bibliography}

Bauman Z. (2011), Kultura w płynnej ponowoczesności, Warszawa.

Burszta J. (1987), Kultura ludowa, [in:] Z. Staszczak (ed.). Słownik etnologiczny, Warszawa-Poznań. Canovan M. (2008), Lud, Warszawa.

Dahlig P. (2013), O wartościowaniu i prognozowaniu tradycji muzycznych, [in:] J. Adamowski, K. Smyk (eds.), Niematerialne dziedzictwo kulturowe: źródła - wartości - ochrona, LublinWarszawa.

Dobroński A. (1998), Znaki tożsamości narodowej według Glogera, Niepodległość i Pamięć no. 5/1. Gloger Z. (1900-1903), Pieśń, [in:] Encyklopedia staropolska, https://literat.ug.edu.pl/glogers/index. htm, accessed: 10.01.2019.

Gloger Z. (1905), Czy lud polski jeszcze śpiewa?, Warszawa.

Grochowski P. (2019), Pieśń w bajce ludowej, [in:] V. Wróblewska (ed.), Polska bajka ludowa. Słownik, http://bajka.umk.pl/slownik/lista-hasel/haslo/?id=241, accessed: 10.01.2019.

Grozdew-Kołacinska W. (ed.) (2014), Raport o stanie tradycyjnej kultury muzycznej, Warszawa, http:// doczz.pl/doc/718697/raport-o-stanie-tradycyjnej-kultury-muzycznej, accessed 10.01.2019.

Ingarden R. (1987), Książeczka o człowieku, Kraków.

Janion M. (2016), Niesamowita Słowiańszczyzna, Kraków.

Kowalczuk U. (2017), „Mapografia” Zygmunta Glogera. Kilka uwag o geografii historycznej ziem dawnej Polski, Bibliotekarz Podlaski no. 1.

${ }_{11}$ Zygmunt Bauman claimed that we do not fully understand the times in which we live. He discusses new socio-cultural threats, such as artificially created needs, dominating cultural relativism, proclaiming the relativity of all truth, a world in which the need for authority or knowledge of tradition is undermined, leading the fashion, consumption, successive blurring of the real boundaries and virtual reality. The postmodern world in which the child grows is opaque, reminiscent of a road without signposts, where equally the adult and the adolescent feel often insecure and helpless. Zygmunt Bauman uses the threshing metaphor to describe the world as full of chaff, in the sense of junk, unnecessary, and not useful to knowledge (Bauman, 2011). 
Ławski J. (2014), Zygmunt Gloger i wiek XIX, [in:] J. Ławski, J. Leończuk (eds.), Zygmunt Gloger- pisma rozproszone 1863-1876, vol. 1, Białystok, http://www.ksiaznicapodlaska.pl/images/20151029/Wstepy.pdf, accessed: 10.01.2019.

Ławski J. (2017), Edukacja i światopogląd. Uniwersytety Zygmunta Glogera, [in:] U. Kowalczuk, Ł. Książyk (eds.), Szkoła Główna. Kręgi wpływów, Warszawa.

Ławski J. (2015). Zygmunt Gloger: prowincja jako centrum świata. Bibliotekarz Podlaski no. 2 http:// www.ksiaznicapodlaska.pl/site/bibliotekarz/31/2_Jaroslaw_Lawski.pdf, accessed: 10.01.2019.

Maroszek M. (2001), Podlasiak z urodzenia - Zygmunt Gloger, Gadki z Chatki. Pismo Folkowe no. 40, https://pismofolkowe.pl/artykul/podlasiak-z-urodzenia-2760, accessed: 10.01.2019.

Mickiewicz A. (1828), Konrad Wallenrod, https://wolnelektury.pl/katalog/lektura/konrad-wallenrod. html\#f835, accessed 10.01.2019.

Samsonowicz H. (1984), Polska Jana Długosza, Warszawa.

Zbrzeźniak U. (2015), Pojęcie ludu w myśli współczesnej, Filo-Sofija no. 29, http://www.filo-sofija.pl/ index.php/czasopismo/article/viewFile/895/870, accessed: 10.01.2019.

XXIII Festival of Many Cultures and Nations "Z Wiejskiego Podwórza" 2018, http://www.festiwalczeremcha.pl, accessed: 10.01.2019. 